\title{
Effects of Gossypol From Cottonseed on Hematological Responses and Plasma $\alpha$-Tocopherol Concentration of Dairy Cows
}

\author{
C. A. Risco, ${ }^{*}$ A. L Adams $, \dagger,{ }^{*},{ }^{1}$ S. Seebohm, ${ }^{*}$ M.-J. Thatcher, ${ }^{*}$ C. R. Staples, $\dagger$ H. H. Van Horn, $\dagger$ \\ L. R. McDowell, $†$ M. C. Calhoun, $\ddagger$ and W. W. Thatcher $†$ \\ ${ }^{*}$ College of Veterinary Medicine and †Animal Sciences Department, \\ University of Florida, Gainesville, FL 32611 \\ ‡ Texas Agricultural Experimental Station. \\ Texas AM University \\ San Angelo, TX. 76901
}

\section{ABSTRACT}

The effects of feeding whole cottonseed (WCS) and bovine somatotropin (bST) administration on hematological responses and plasma $\alpha$-tocopherol concentrations of lactating dairy cattle were examined. After parturition, multi and primiparous Holstein cows $(\mathrm{n}=159)$ were assigned randomly to a $2 \times 2$ factorial arrangement of treatments consisting of ( 0 or $15 \%$ WCS and 0 or 208 $\mathrm{mg}$ of bST injected every $2 \mathrm{wk}$ starting within $7 \mathrm{~d}$ after calving. Blood samples were collected from a subset group of 64 cows at 14, 28, 42, and $56 \mathrm{~d}$ postpartum. Blood was collected from all cows $(\mathrm{n}=159)$ at 75,96 and $120 \mathrm{~d}$ postpartum. Blood samples were analyzed for $\alpha$-tocopherol and total and (+)- and (-)-gossypol in plasma. Erythrocyte osmotic fragility, hemoglobin and hematocrit also were determined in blood. The mean concentrations of $\alpha$-Tocopherol, total, and (+) - and (-) gossypol were higher in cows fed WCS regardless of bST administration and plateaued by d 75 postpartum. Hematocrit and hemoglobin concentrations were not affected by treatments. Erythrocyte osmotic fragility was higher in cows fed WCS, but the increase was attenuated when bST was injected (diet $\times$ bST interaction). No clinical signs of gossypol toxicity were observed in the cows consuming the WCS.

(Key words: gossypol, whole cottonseed, bovine somatotropin, $\alpha$-tocopherol, erythrocytes, dairy cows)

Abbreviation key: $\alpha$-T $=\alpha$-tocopherol, $\mathbf{C S H}=$ cottonseed hulls, EOF = erythrocyte osmotic fragility, WCS = whole cottonseed.

Received June 13, 2002.

Accepted July 26, 2002.

Corresponding author: C. A. R.; e-mail: RiscoC@mail.vetmed. ufl.edu.

${ }^{1}$ The work is that of the individual in her personal capacity as an animal scientist and not that of the FDA.

\section{INTRODUCTION}

Gossypol is a bi-naphthyl aldehyde that naturally occurs in the cotton plant, Gossypium spp. (Adams et al., 1960). Because gossypol has been recognized since the turn of the century to be toxic to animals, a limiting factor of feeding whole cottonseed (WCS) and its byproducts is its gossypol content (Morgan, 1989; Risco and Chase, 1997). Whole cottonseed is a good source of energy, fiber and protein in diets of lactating dairy cattle. Approximately $3.5 \mathrm{~kg}$ per cow per day (15\% of dietary DM) is commonly fed in certain regions of North America and throughout the world, with excellent results in maintaining high milk production and milk fat percentage (Coppock et al., 1987; Arieli, 1998).

Nonruminants and preruminant lambs and calves are more susceptible to the toxic effect of gossypol than mature ruminants (Morgan, 1989). The ability of mature ruminants to tolerate gossypol appears to be due to the binding of gossypol to soluble proteins in the rumen (Reiser and $\mathrm{Fu}, 1962$ ). However, reports of gossypol toxicity in mature cattle demonstrate that the capacity of the rumen to detoxify gossypol can be exceeded (Lindsey et al., 1980; Smalley and Bicknell, 1982). Dietary gossypol from cottonseed products has caused hematological changes in ruminants, which may affect health and performance (Lindsey et al., 1980; ColinNegrete et al., 1996). Vitamin $\mathrm{E}$ is an antioxidant that prevents the damage of free radicals at the cellular level. As a promoter of free radicals, Gossypol may reduce cellular antioxidants. Bender et al. (1988) found that vitamin E, ascorbate, glutathione peroxidase, and other antioxidants were reduced by feeding rats high levels of gossypol. In dairy cattle, Lane and Stuart (1990) found that feeding high amounts of gossypol decreased plasma vitamin E levels, indicating a possible relationship between gossypol toxicity and vitamin E. Pre- and postpartum consumption of free gossypol impaired aspects of calf skeletal development with lowered serum vitamin $\mathrm{E}$ and $\beta$ carotene (Willard et al., 1995). 
Exogenous bST is used widely in dairy cattle to increase milk production An increase in milk yield from bST has been associated with reduced reproductive performance due to a decline in conception rates and greater days open (Bauman, D. E., 1992). However, doses below those recommended for increased milk production may enhance reproductive function (Stansiewski, et al., 1992). Bovine somatotropin alters liver function, and because gossypol accumulates in the liver (Morgan, 1989; Risco et al., 1992; Risco and Chase, 1997) the possibility of an interaction between exogenous bST and gossypol needs to be examined. Bovine somatotropin may alter gossypol metabolism in the liver with potential positive or negative effects in lactating dairy cows consuming WCS. Therefore, the objective of the present study was to examine the effect of WCS on hematological parameters and plasma $\alpha$-Tocopherol and gossypol concentrations of lactating dairy cattle receiving a lower-dose regimen of bST.

\section{MATERIALS AND METHODS}

\section{Animals, Diets, and Management}

This study was conducted at the Dairy Research Unit of the University of Florida in Hague, Florida, from September 22, 1996, to June 19, 1997. The experiment was part of a major project to study the effects of WCS feeding and a lower dose of bST (Posilac, Monsanto, Co., St. Louis, MO) on milk production and reproductive performance in early postpartum dairy cows (Adams et al., 1998). Cows were housed in an open-sided, freestall barn with a concrete floor. Diets were formulated to meet the requirements of lactating Holstein cows (NRC, 1988), and fed as a total mixed ration (Table 1). A total of 159 Holstein cows were enrolled in the study. Multiparous $(\mathrm{n}=73)$ and primiparous cows $(\mathrm{n}=83)$ were assigned randomly at calving to treatments in a $2 \times 2$ factorial arrangement of diets (0 or 15\% WCS) and bST (0 or $208 \mathrm{mg}$ ). The bST was injected subcutaneous every 2 wk starting within $7 \mathrm{~d}$ of calving. This dose of bST is less than $50 \%$ of the standard commercial dose rate. Because bST was administered at a reduced label dose and prior to wk 9 of lactation, it was considered an offlabel use. Cows were started on the diets within $24 \mathrm{hr}$ after calving. Animals continued on treatment assignments until $120 \mathrm{~d}$ postpartum. After this time, all animals were fed the basal diet with $15 \%$ of concentrate dry matter replaced with WCS and received the label dose $(500 \mathrm{mg})$ of bST at 2 -wk intervals.

\section{Plasma and Diet Analysis}

Blood samples were collected via venipuncture of the coccygeal vein with an 18 gauge needle into heparin

Table 1. Ingredient and chemical composition of experimental diets fed to lactating dairy cows.

\begin{tabular}{|c|c|c|}
\hline \multirow[b]{2}{*}{ Item } & \multicolumn{2}{|c|}{$\%$ of DM } \\
\hline & $15 \% \mathrm{WCS}$ & $0 \% \mathrm{WCS}$ \\
\hline \multicolumn{3}{|l|}{ Ingredients } \\
\hline Corn silage & 21.70 & 22.37 \\
\hline Alfalfa hay & 9.13 & 11.69 \\
\hline Cottonseed hulls & 5.57 & 5.57 \\
\hline Citrus pulp & 10.06 & 9.94 \\
\hline Hominy & 15.36 & 20.31 \\
\hline Distillers grains & 9.19 & 13.40 \\
\hline Soybean meal & 8.80 & 11.38 \\
\hline Whole cottonseed & 14.95 & 0.00 \\
\hline Mineral mix ${ }^{1}$ & 5.34 & 5.34 \\
\hline \multicolumn{3}{|l|}{ Chemical composition } \\
\hline $\mathrm{CP}^{3}$ & 18.06 & 18.05 \\
\hline Ruminally undegradable protein ${ }^{2}$ & 6.19 & 6.58 \\
\hline NEL $(\mathrm{Mcal} / \mathrm{kg})^{2}$ & 1.71 & 1.65 \\
\hline $\mathrm{ADF}^{3}$ & 24.21 & 20.84 \\
\hline Ether extract ${ }^{3}$ & 6.04 & 3.56 \\
\hline $\mathrm{Ca}^{3}$ & 1.10 & 1.09 \\
\hline $\mathrm{P}^{3}$ & 0.57 & 0.57 \\
\hline $\mathrm{Mg}^{3}$ & 0.35 & 0.33 \\
\hline $\mathrm{K}^{3}$ & 1.44 & 1.49 \\
\hline $\mathrm{S}^{3}$ & 0.25 & 0.25 \\
\hline
\end{tabular}

${ }^{1}$ Contained $12.0 \% \mathrm{Ca}, 2.8 \% \mathrm{P}, 2.9 \% \mathrm{Mg}, 1.0 \% \mathrm{~S}, 1.6 \% \mathrm{~K}, 7.8 \% \mathrm{Na}, 800 \mathrm{ppm}$ of $\mathrm{Zn}, 320 \mathrm{ppm}$ of $\mathrm{Cu}, 800$ $\mathrm{ppm}$ of Fe, $800 \mathrm{ppm}$ of $\mathrm{Mn}, 242,000 \mathrm{IU}$ of vitamin $\mathrm{A} / \mathrm{kg}, 35,200 \mathrm{IU}$ of vitamin D/kg, and 880 IU of vitamin $\mathrm{E} / \mathrm{kg}$ (DM basis).

${ }^{2}$ Calculated from NRC, 1989.

${ }^{3}$ Values obtained from chemical analysis. 
and EDTA-containing vacutainer blood collection tubes. Blood samples were collected from a subset group of the 159 cows assigned to the study ( $\mathrm{T} 0, \mathrm{n}=13$ for $0 \%$ WCS, -bST; T1, $\mathrm{n}=16$ for $15 \%$ WCS, -bST; T2, $\mathrm{n}$ $=19$ for $0 \% \mathrm{WCS},+\mathrm{bST}$; T3, $\mathrm{n}=16$ for $15 \% \mathrm{WCS},+$ bST) at 14, 28, 42 and $56 \mathrm{~d}$ postpartum. Blood was collected from all cows in the study $(\mathrm{n}=159)$ at 75,96 and $120 \mathrm{~d}$ postpartum. Blood was centrifuged for 25 min at $700 \times$ g. Plasma was removed and stored at $-20^{\circ} \mathrm{C}$ until it was analyzed for $\alpha$-tocopherol $(\boldsymbol{\alpha}$-T), total and (+)- and (-)-gossypol. Erythrocyte osmotic fragility (EOF), hemoglobin concentration and hematocrit also were analyzed in blood. Samples of WCS, cottonseed hulls (CSH) and mixed diets (0\% and 15\% WCS) were collected every $3 \mathrm{wk}$ and stored at room temperature.

Plasma $\alpha$-T was determined by high performance liquid chromatography (HPLC) as described by Njeru et al. (1995). Samples of plasma, WCS and CSH were shipped in dry ice to the Texas A\&M University Agricultural Center (San Angelo, TX) for gossypol analyses. High performance liquid chromatography was used to determine total and (+)- and (-)-gossypol in plasma (Kim and Calhoun, 1995) and WCS (Hron et al., 1999). Total and free gossypol concentrations in WCS were also determined by the official methods of the American Oil Chemists' Society (AOCS, 1988a; 1988b). Cottonseed hulls were analyzed for total gossypol by the official methods of the American Oil Chemists' Society (AOCS, 1988b) and (+)-(-) gossypol by high performance liquid chromatography. Samples of the mixed diets $(0 \%$ and 15\% WCS) were sent to Mid Continent Laboratory
(Memphis, TN) for determination of total and free gossypol (AOCS, 1988a; 1988b). Samples of the WCS and CSH fed in the experiment were analyzed for vitamin E content using previously described procedures (Njeru et al., 1995).

Erythrocyte osmotic fragility was determined as described by Nelson (1979) by measuring the percentage of erythrocytes hemolyzed in a $0.6 \%$ buffered saline solution. Hemoglobin content of blood was determined using a colorimetric procedure (Sigma Chemical Co., St. Louis, MO) and hematocrit was determined using a micro hematocrit centrifuge (IEC MB Centrifuge, Needham Heights, MA).

\section{Statistical Analysis}

Data were analyzed by least squares analysis of variance using GLM and mixed model procedures of SAS (1996). Plasma concentrations of $\alpha$-T, gossypol and hemoglobin, as well as percentage of erythrocyte fragility and hematocrit were analyzed as dependent variables. Initially, parity was included in the statistical model and was not significant $(P>0.25)$. Therefore, it was removed from the final statistical model which included, effects of treatments (diet, bST), cow within treatment, experimental day, treatment $\times$ day interactions and residuals. The $\mathrm{F}$ tests for the effects of treatment were performed using the mean squares of cowwithin-treatment as the error term, cows were considered random. Orthogonal contrasts tested were 1) WCS vs. no WCS 2) bST vs. no bST and 3) interaction of diet

Table 2. Least squares means and SE of plasma $\alpha$-tocopherol and total and (+)- and (-)-gossypol in plasma for d 76, 96 and 120 postpartum for cows fed diets of 0 or 15\% WCS and injected with 0 or $208 \mathrm{mg}$ of bST 1,2 (Treatment effect, $P<0.001$ ).

\begin{tabular}{|c|c|c|c|c|c|}
\hline & \multicolumn{2}{|c|}{$0 \% \mathrm{WCS}$} & \multicolumn{2}{|c|}{$15 \% \mathrm{WCS}$} & \multirow[b]{2}{*}{ SEM } \\
\hline & $-\mathrm{bST}$ & $+\mathrm{bST}$ & $-\mathrm{bST}$ & $+\mathrm{bST}$ & \\
\hline \multicolumn{6}{|c|}{$\alpha$-Tocopherol $\mu \mathrm{g} / \mathrm{ml}$} \\
\hline $75 \mathrm{~d}$ & 7.56 & 4.25 & 10.25 & 10.17 & 0.53 \\
\hline $96 \mathrm{~d}$ & 7.34 & 6.99 & 10.69 & 10.47 & 0.48 \\
\hline $120 \mathrm{~d}$ & 7.86 & 7.45 & 10.34 & 10.47 & 0.50 \\
\hline \multicolumn{6}{|c|}{ Total gossypol, $\mu \mathrm{g} / \mathrm{ml}$} \\
\hline $75 \mathrm{~d}$ & 0.81 & 1.16 & 3.01 & 2.97 & 0.24 \\
\hline $96 \mathrm{~d}$ & 0.85 & 0.98 & 3.62 & 3.12 & 0.25 \\
\hline $120 \mathrm{~d}$ & 0.86 & 1.18 & 3.64 & 3.09 & 0.28 \\
\hline \multicolumn{6}{|c|}{ (+)-Gossypol, $\mu \mathrm{g} / \mathrm{ml}$} \\
\hline $75 \mathrm{~d}$ & 0.33 & 0.50 & 1.23 & 1.23 & 0.10 \\
\hline $96 \mathrm{~d}$ & 0.32 & 0.39 & 1.49 & 1.27 & 0.11 \\
\hline $120 \mathrm{~d}$ & 0.37 & 0.49 & 1.47 & 1.26 & 0.11 \\
\hline \multicolumn{6}{|c|}{ (-)-Gossypol, $\mu \mathrm{g} / \mathrm{ml}$} \\
\hline $75 \mathrm{~d}$ & 0.49 & 0.67 & 1.78 & 1.75 & 0.14 \\
\hline $96 \mathrm{~d}$ & 0.52 & 0.58 & 2.13 & 1.83 & 0.14 \\
\hline $120 \mathrm{~d}$ & 0.49 & 0.69 & 2.16 & 1.84 & 0.17 \\
\hline
\end{tabular}

${ }^{1}$ The number of cows sampled for each treatment were $0 \% \mathrm{WCS}-\mathrm{bST}, 36 ; 0 \% \mathrm{WCS}+\mathrm{bST}, 42 ; 15 \% \mathrm{WCS}$ - bST, 35; $15 \%$ WCS - bST 35; $15 \%$ WCS + bST, 46.

${ }^{2}$ Cows were injected with either 0 or $208 \mathrm{mg}$ of bST every 2 wk starting within $7 \mathrm{~d}$ after calving. 


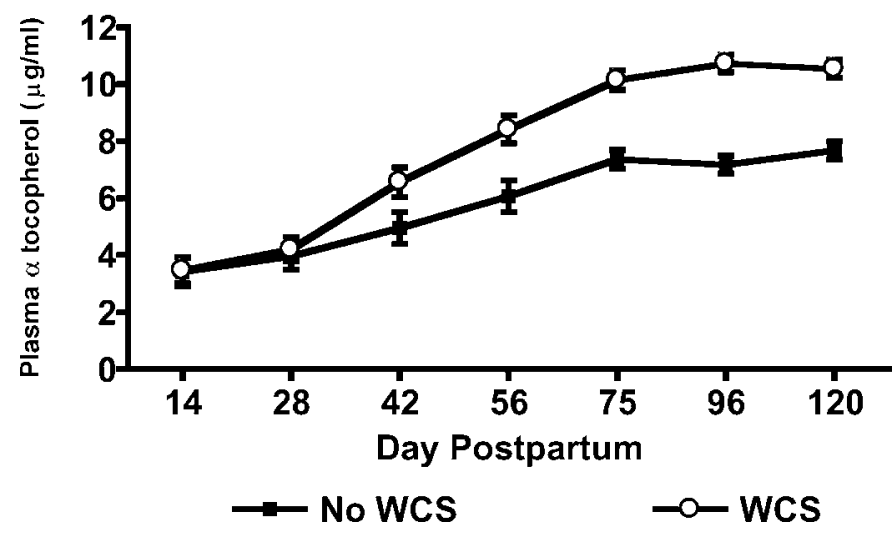

Figure 1. Effect of feeding whole cottonseed on concentration of plasma $\alpha$-Tocopherol in lactating dairy cows. Treatment, $P<0.001$; Day, $P<0.001$; Treatment $\times$ Day, $P<0.001$. Mean diet differences were significant from d 42 to 120 postpartum.

and bST. The response variables involving repeated measurements were analyzed by testing homogeneity of regression curves for day trends as described by Wilcox et al., 1990. Briefly, a single polynomial regression for day was fitted to an individual dependent variable (singled pooled curve), and the differences from fitting individual regressions for effects of diet, bST, and diet $\times \mathrm{bST}$ interaction curves were tested. PDIFF mean comparisons were used also to examine differences among days postpartum for plasma concentrations of total gossypol and (+)- and (-) gossypol isomers.

\section{RESULTS}

Free and total gossypol concentrations in the WCS $(\mathrm{n}=12)$ were $0.56 \pm 0.02 \%$ and $0.60 \pm 0.01 \%$, respectively. The proportions of the (+)- and (-)-isomers of gossypol in the seed were $58.8 \pm 0.3 \%$ and $41.2 \pm 0.3 \%$, respectively. Total gossypol concentrations in the hulls ( $\mathrm{n}=12$ ) were $0.20 \pm 0.04 \%$. The proportion of the (+)and (-)-isomers of gossypol in the hulls was $59.9 \pm 0.8 \%$ and $40.1 \pm 0.8 \%$. Total gossypol concentrations were $0.10 \pm 0.07 \%$ and $0.05 \pm 0.03 \%$ for the 15 and $0 \%$ WCS mixed diets $(\mathrm{n}=12)$, respectively. Concentrations of vitamin E were $56.3 \mu \mathrm{g} / \mathrm{g}$ and $19.9 \mu \mathrm{g} / \mathrm{g}$ for WCS and $\mathrm{CSH}$, respectively. Individual cow DMI was not determined in the present study. Group averages for DMI were $22.7 \mathrm{~kg}$ and $22.0 \mathrm{~kg}$ for the 0 and $15 \%$ WCS mixed diets. The calculated daily intakes of total gossypol after peak DMI based on WCS and CSH values, were approximately $22.6 \mathrm{~g} / \mathrm{d}$ for cows fed the 15\% WCS diet (20 g from the $15 \% \mathrm{WCS}$ and $2.6 \mathrm{~g}$ from the $\mathrm{CSH}$ ) and $2.6 \mathrm{~g} /$ $\mathrm{d}$ for cows fed the $0 \%$ WCS diet (2.6 $\mathrm{g}$ from $\mathrm{CSH})$.

The effects of diet and bST administration on the concentrations of plasma $\alpha$-T, total and (+)- and (-)- gossypol were first analyzed for plasma samples collected at 75, 96 and $120 \mathrm{~d}$ postpartum when all cows were sampled (T0 $\mathrm{n}=36$; T1 $\mathrm{n}=35$; T2 $\mathrm{n}=42$; T3 $\mathrm{n}=$ 46). The concentrations of $\alpha-\mathrm{T}$ and total and (+)- and (-)-gossypol were greater in cows fed WCS regardless of bST administration $(P<0.001)$ (Table 2). Day of measurement postpartum was not significant, suggesting that the concentrations of these plasma constituents had plateaued by d 75 postpartum (Table 2 ).

The same plasma compounds were analyzed for the subset group of cows sampled from d 14 to 120 postpartum ( $\mathrm{T} 0 \mathrm{n}=13$; $\mathrm{T} 1 \mathrm{n}=16$; $\mathrm{T} 2 \mathrm{n}=19$; T3 $\mathrm{n}=16$ ) The concentrations of $\alpha$-T, and total and (+)- and (-)gossypol over time of sampling differed significantly $(P$ $<0.01$ ) among treatments when analyzed by homogeneity of regression. Effects of diet, regardless of bST administration were detected for all the responses $(P<$ 0.01). During the first $28 \mathrm{~d}$ postpartum, the concentration of $\alpha$-T did not differ between cows due to diet. By d 42 to 75 postpartum the cows fed WCS had greater concentrations of plasma $\alpha$-T, which was maintained throughout the 120-d period $(P<0.001$; Figure 1).

Plasma levels of total, and (+)- and (-)-gossypol increased in cows fed WCS from d 14 to $\mathrm{d} 96$, and appeared to have reached a plateau by d 96 postpartum; whereas, plasma levels changed little during this period in cows receiving only CSH (Figures 2 and 3).On d 28 postpartum, and for all sampling times thereafter, plasma concentrations of total and $(+)$ - gossypol were greater $(P<$ $0.0001)$ for cows receiving WCS than for those receiving only CSH. In contrast, plasma (-) -gossypol levels were not higher for cows fed WCS than for those receiving only CSH until d 42 postpartum $(P<0.0001)$. At 14 $\mathrm{d}$ the positive isomer was the predominant isomer in

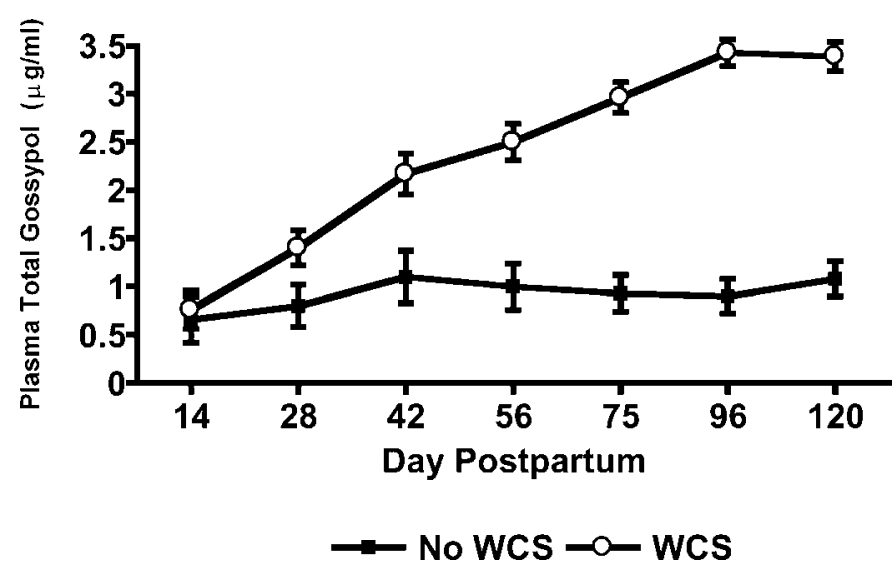

Figure 2. Effect of feeding whole cottonseed on concentration of plasma total gossypol in lactating dairy cows. Treatment, $P<0.001$; Day, $P<0.001$; Treatment $\times$ Day, $P<0.001$. Mean diet differences were significant from d 28 to 120 postpartum. 
plasma of cows fed WCS, representing about $60 \%$ of total plasma gossypol. However, from 14 to $96 \mathrm{~d}$ the minus isomer accumulated in plasma at about twice the rate of the positive isomer $(1.8 \mathrm{ng} / \mathrm{ml}$ for the minus isomer versus $0.95 \mathrm{ng} / \mathrm{ml}$ for the positive isomer), and by $96 \mathrm{~d}$ postpartum represented about $60 \%$ of total plasma gossypol.

Hematological measurements were analyzed by the mixed model procedure and treatment effects compared by orthogonal contrasts for d 75, 96, and 120 postpartum (Figure 3). Hematocrit and hemoglobin concentrations were not affected by treatments (Table 3). However, EOF was elevated in cows consuming the WCS $(P<0.001)$. EOF decreased as d postpartum increased in cows fed WCS. The increase in erythrocyte osmotic fragility due to consumption of WCS was not as great when bST was administered (diet $\times$ bST interaction, $P$ $<0.06$ ) (Figure 4).

\section{DISCUSSION}

This experiment examined the effect of dietary gossypol on hematological components and plasma $\alpha$-T con-
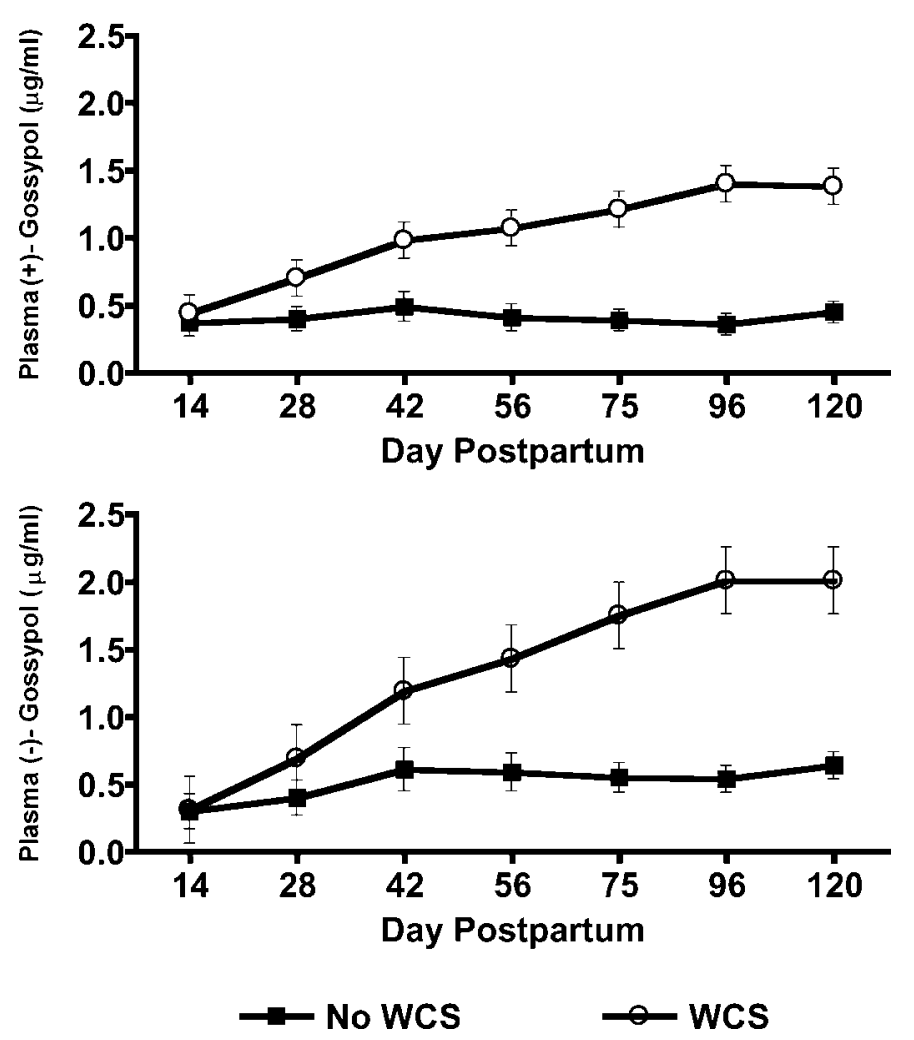

Figure 3. Effect of feeding whole cottonseed on concentration of plasma (+)- and (-)-gossypol isomers in lactating dairy cows. Treatment, $P<0.001$; Day, $P<0.001$; Treatment $\times$ Day, $P<0.001$ Mean diet differences were significant from d 28 to 120 for (+)-gossypol and from 42 to $120 \mathrm{~d}$ for (-)-gossypol. centrations of lactating dairy cattle receiving a lower dose regimen of bST as previously reported by Adams et al. (1998). During the experiment approximately 3.3 $\mathrm{kg}$ of WCS (15\% DM) and $1.3 \mathrm{~kg}$ of CSH $(5.6 \% \mathrm{DM})$ was fed per day, which provided an estimated $22.6 \mathrm{~g}$ of total gossypol per day after peak DMI. This amount of WCS is often fed in commercial dairy herds. We did not see any clinical signs related to gossypol toxicity affecting the cardiopulmonary system such as respiratory distress, distention of the jugular vein or death attributed to congestive heart failure (Smalley and Bicknell, 1982; Morgan, 1989; Risco and Chase, 1997). In contrast, lactating dairy cows consuming $24 \mathrm{~g}$ of gossypol per day from a diet that contained $45 \%$ solvent extracted cottonseed meal exhibited reduced milk production, respiratory distress and one death (Lindsey et al., 1980). A 10\% mortality rate was reported in lactating dairy cattle consuming 18 to $30 \mathrm{~g}$ of free gossypol per day from WCS for an 8-mo period, in which lesions were found on postmortem examination consistent with gossypol toxicity affecting the heart, lungs and liver (Smalley and Bicknell, 1982). In the present study, total gossypol values in plasma were less than the recommended safe concentration for mature ruminants. Calhoun et al. (1995) considered total gossypol levels in plasma $\leq 5$ $\mu \mathrm{g} / \mathrm{ml}$ safe for dairy cattle fed cotton byproducts for extended periods.

The concentration of plasma $\alpha$-T in all treatment groups was similar to values reported previously for lactating dairy cows supplemented with vitamin E (Weiss et al., 1990; Weiss et al., 1992). In all treatment groups, plasma $\alpha$-T concentrations were low during the first $28 \mathrm{~d}$ postpartum and increased from 28 to $75 \mathrm{~d}$ postpartum. There was little change in $\alpha$-T levels from 75 to $120 \mathrm{~d}$. Plasma $\alpha$-T values appear to be influenced by stage of lactation in agreement with Weiss et al. (1992), in which plasma levels of $\alpha$-T dropped by about $50 \%$ at calving, remained low until 20 to $30 \mathrm{~d}$ postpartum, and then increased up to $60 \mathrm{~d}$ postpartum. The drop in plasma $\alpha$-T during the early postpartum period could be due to decreased feed intake and therefore, decreased intake of dietary vitamin $\mathrm{E}$. The decrease of $\alpha$-T concentration in plasma at this time also has been attributed to a decreased transport capacity for the vitamin in response to utilization of plasma lipoproteins by the mammary gland (Weiss et al. 1992).

Throughout the experiment, cows fed WCS had greater concentrations of plasma $\alpha$-T whether or not they received bST compared to cows that did not receive WCS. The greater concentration observed might be attributed to the vitamin E content of the WCS fed in the present study. The concentration of vitamin $\mathrm{E}$ was 59.4 $\mu \mathrm{g} / \mathrm{g}$ for the WCS and $19.9 \mu \mathrm{g} / \mathrm{g}$ for the CSH such that cows fed the WCS diet received almost twice the amount 
Table 3. Least squares means and SE of hematological responses in plasma for d 76, 96 and 120 postpartum for cows fed diets of 0 or $15 \%$ WCS and injected with 0 or $208 \mathrm{mg}$ of $\mathrm{bST}^{1,2}$ (Day, $P<0.001$; Treatment $\times$ Day, $P<0.001$ for hematocrit).

\begin{tabular}{|c|c|c|c|c|c|}
\hline & \multicolumn{2}{|c|}{$0 \% \mathrm{WCS}$} & \multicolumn{2}{|c|}{$15 \%$ WCS } & \multirow[b]{2}{*}{ SEM } \\
\hline & -bST & $+\mathrm{bST}$ & -bST & $+\mathrm{bST}$ & \\
\hline \multicolumn{6}{|c|}{ Hematocrit, \% } \\
\hline $75 \mathrm{~d}$ & 27.7 & 26.7 & 27.3 & 27.9 & 0.4 \\
\hline $96 \mathrm{~d}$ & 27.9 & 27.6 & 28.1 & 28.1 & 0.4 \\
\hline $120 \mathrm{~d}$ & 29.2 & 28.1 & 28.9 & 27.4 & 0.4 \\
\hline \multicolumn{6}{|c|}{ Hemoglobin, g/dl } \\
\hline $75 \mathrm{~d}$ & 10.4 & 10.4 & 10.5 & 10.7 & 0.2 \\
\hline $96 \mathrm{~d}$ & 10.4 & 10.3 & 10.5 & 10.5 & 0.2 \\
\hline $120 \mathrm{~d}$ & 10.6 & 10.2 & 10.8 & 10.6 & 0.2 \\
\hline
\end{tabular}

${ }^{1}$ The number of cows sampled for each treatment were $36(0 \% \mathrm{WCS}-\mathrm{bST}), 42(0 \% \mathrm{WCS}+\mathrm{bST}), 35(15 \%$ WCS - bST), 35 (15\% WCS - bST), and 46 (15\% WCS + bST).

${ }^{2}$ Cows were injected with either 0 or $208 \mathrm{mg}$ of bST every 2 wk starting within $7 \mathrm{~d}$ after calving.

of vitamin E. Weiss et al. (1990) reported a positive correlation between vitamin $\mathrm{E}$ intake and plasma $\alpha$ - $\mathrm{T}$ concentration. Unlike the reports by Bender et al. (1988) and Lane and Stuart (1990), gossypol consumption in the present study did not lower plasma $\alpha$-T concentrations. Velasquez-Perreira et al. (1999) reported that gossypol did not lower $\alpha$-T concentration in plasma of male Holstein calves fed a cottonseed meal diet.

Cows fed WCS had greater concentrations of plasma total (+)- and (-)-gossypol than those fed only CSH. Calhoun et al. (1995) suggested that plasma gossypol concentrations reflect the availability of gossypol in the diet and the proportion of isomers being fed. The proportion of the (+)-gossypol isomer was higher than the (-)gossypol isomer in the WCS fed in the present study. The plasma gossypol values observed in the present
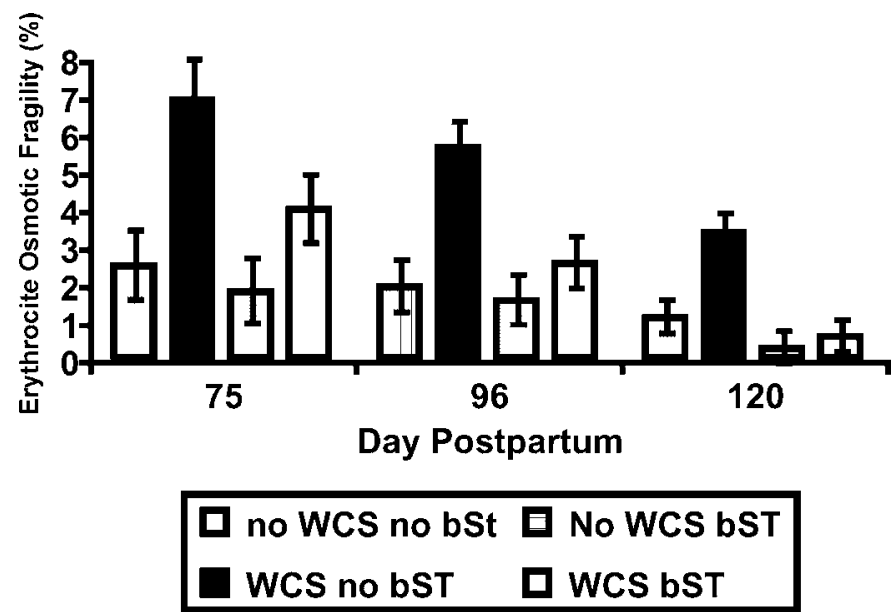

Figure 4. Effect of feeding whole cottonseed on erythrocyte osmotic fragility. Treatment, $P<0.001$; Day, $P<0.001$; orthogonal contrasts: diet, $P<0.001$; bST, $P<0.005$; diet $\times$ bST, $P<0.06$ ). study are similar to those reported by Lindsey et al. (1980) who fed $24 \mathrm{~g}$ per day of gossypol from a cottonseed meal to lactating dairy cows and Velasquez-Perreira et al. (1999) who fed $400 \mathrm{mg}$ of free gossypol/kg of diet to Holstein calves.

Erythrocyte osmotic fragility is a measure of the ability of the erythrocyte membrane to resist osmotic stress when erythrocytes are incubated in different salt solutions with decreasing salt concentrations. An increase in EOF has been a consistent finding in various gossypol studies (Lindsey et al., 1980; Hawkins et al., 1985; Risco et al., 1993; Collin-Negrete et al., 1996; Velasquez-Perreira et al., 1999). Gossypol binds to lipid bilayers and alters membrane permeability (Reyes et al., 1984). In the present study cows fed WCS and not treated with bST experienced a higher EOF at $0.65 \%$ saline solution compared to cows fed WCS and treated with bST. Administration of bST may have had a sparring effect on gossypol-induced EOF. However, this finding must be interpreted with caution. The degree of EOF observed in the present study is mild compared to other studies that used the same procedure. In those studies (Risco, 1993; Velasquez-Perreira et al., 1999) the gossypol-induced EOF was in the magnitude of 30 to $50 \%$, compared to $<10 \%$ in the present study. Indeed $<10 \%$ of EOF is within the range reported for Brahman bulls (Risco et al., 1993) and calves (Velasquez-Perreira et al., 1999) fed a gossypol-free diet. Furthermore, Hawkins et al. (1985) found no change in EOF of lactating dairy cows fed WCS at $18.5 \%$ of dietary DM, containing $0.235 \%$ total gossypol for one lactation. It is noteworthy that, evidence of hematuria, a clinical sign related to intravascular hemolysis of erythrocytes, was not observed in cows that consumed WCS in the present study.

When intravascular hemolysis occurs, hemoglobin concentration increases and hematocrit decreases in 
blood. In the present study, blood hemoglobin and hematocrit were not different between treatments and were within normal values reported for cattle (Kaneko, 1989). Thus, the effect of gossypol on erythrocyte function was minimal in cows fed WCS in the present study in agreement with our previous reports (Risco et al., 1993; Velasquez-Perreira et al., 1999). In the present study, the normal hemoglobin and hematocrit values observed might be related to the $\alpha$-T concentrations found in the blood of cows fed WCS, which were above the recommended minimum plasma values of $4 \mu \mathrm{g} / \mathrm{ml}$ for healthy dairy cattle (Smith et al., 1988). Gossypol can inhibit glucose-6-phosphate dehydrogenase, causing a decrease in NADPH production, which is necessary to reduce glutathione, an important component of the cell antioxidant systems. Enzyme inhibition in this pathway or excess oxidants may cause reduced hemoglobin and hematocrit values. Therefore, increased concentrations of $\alpha$-T in the blood of WCS-fed cows may have had an antioxidant effect. In the report by Weiss et al. (1992), concentrations of $\alpha$-T in erythrocytes were correlated highly with plasma concentrations (after adjustment for plasma lipid content). Apparently, $\alpha$-T can exchange freely between erythrocytes and plasma lipids. Hemoglobin and hematocrit were decreased in calves receiving a cottonseed meal in the grain mix and vitamin $\mathrm{E}$ supplementation counteracted this effect but not the adverse effect on EOF (Velasquez-Perreira et al., 1999). Results of Velasquez-Perreira et al. (1999) suggests that the effect of gossypol on EOF may be related to the alteration of membrane integrity through mechanisms not related to decreased antioxidant concentrations.

When total gossypol values for the WCS and CSH were used to calculate the gossypol content of the mixed diets, the total gossypol concentrations were higher than when the total mixed WCS diets were analyzed. The method used to determine total gossypol concentrations in the whole seed, cottonseed hulls and mixed diets was performed by aniline reaction procedures according to official methods of AOAC (1988a; 1988b) for free gossypol and total gossypol, respectively. However, this method is unsatisfactory when applied to mixed feed (Risco and Chase, 1997). The problem with this method is incomplete recovery of free gossypol from feed mixtures and the extraction of other feed constituents interfering in the subsequent colorimetric determinations, resulting in a much lower gossypol content when compared to analysis of the WCS or CSH.

Gossypol is a chiral molecule due to its steric hindrance to rotation about the internaphthyl bond. The isomeric ratio of gossypol appears to be related to Gossypium species. The seed used in this study was upland (Gossypium hirsutum). The total and free gossypol val- ues obtained for the cottonseed used in this study were similar to the average for whole, fuzzy cottonseed in the southeastern United States (Foster and Calhoun, 1995). An interesting finding in this experiment is the higher gossypol concentration of the $\mathrm{CSH}$, which was about twice that previously reported (Foster and Calhoun, 1995). Based upon the gossypol content of the hulls and the average gossypol content of the meats in the seed of the 12 samples of WCS, the percentage of meats in the hulls used in the present study averaged $17 \%$ with a range of 13 to $22 \%$. This amount of meats in the cottonseed hulls resulted in a greater than expected concentration of the plasma gossypol in the control group. It also suggests an incomplete removal of the seed from the final cottonseed hull product during processing.

Due to its stereospecific binding properties, the (-)gossypol enantiomer becomes bound to plasma proteins and appears to be more toxic because it will bind more readily to tissues (Wang et al., 1992). Perhaps, the lack of gossypol toxicity seen in the present study may be related to the higher proportion of the (+)-gossypol isomer in the WCS and the level of cottonseed fed.

\section{CONCLUSIONS}

Whole cottonseed fed at $15 \%$ of diet DM provided an estimated $23 \mathrm{~g}$ per day of free gossypol that did not result in deaths or clinical signs related to gossypol toxicity. The cows fed WCS had a higher concentration of plasma $\alpha$-T, total gossypol, (+)- and (-)-gossypol isomers. Gossypol concentrations in blood were within the recommended safe concentrations. Administration of $208 \mathrm{mg}$ of recombinant bST appeared to counteract the effect of gossypol on EOF.

\section{ACKNOWLEDGMENTS}

Supported by a grant from the Florida Dairy Farmers Milk Check-Off Program. The authors thank personnel of The University of Florida, Dairy Research Unit, Hague, Florida, for their support. This manuscript was published as Florida Exp. Sta. J. Ser. R-09131

\section{REFERENCES}

Adams, R., T. J. Geissman, and J. D. Edwards. 1960. Gossypol, A pigment of cottonseed. Chem. Rev. 60:555-574.

Adams, A. L., C. R. Staples, H. H. Van Horn, D. Ambrose, T. Kassa, W. W. Thatcher, C. J. Wilcox, and C. A. Risco. 1998. Effects of whole cottonseed and low dose bST on milk production and reproduction of early postpartum dairy cows. J. Dairy Sci. 81(Suppl. 1):306. (Abstr.).

AOCS. 1988a. Determination of free gossypol. Official method. Ba 758 in Official and Tentative Methods of Analysis. 3rd ed. Am. Oil Chem. Soc. Champaign, IL. 
AOCS. 1988b. Determination of total gossypol. Official Method Ba 8-78. Official and Tentative Methods of Analysis. 3rd ed. Am. Oil Chem. Soc. Champaign, IL.

Arieli, A. 1998. Whole cottonseed in dairy cattle feeding: A review. Anim. Feed Sci. Technol. 72:97-110.

Bauman, D. E. 1992. Bovine somatotropin: review of an emerging technology. J. Dairy Sci. 75:3432.

Bender, H. S., S. Z. Derolf, and H. P. Misra. 1988. Effects of gossypol on the antioxidant defense system of the rat testis. Arch. Androl. 21:59-67.

Calhoun, M. C., S. W. Kuhlman, and B. C. Baldwin Jr. 1995. Assessing the gossypol status of cattle fed cotton feed products. Pages 114 in: Proc. Pacific Northwest, Anim. Nutr. Conf. Portland, OR.

Colin-Negrete, J., H. E. Kiesling, T. T. Ross and J. F. Smith. 1996. Effect of whole cottonseed on serum constituents, fragility of erythrocyte cells, and reproduction of growing Holstein heifers. J. Dairy Sci. 79:2016-2023.

Coppock, C. E., J. K. Lanham and J. I. Horner. 1987. A review of the nutritive value and utilization of whole cottonseed, cottonseed meal and associated by-products by dairy cattle. Anim. Feed Sci. Technol. 18:89-129.

Foster, L. A. Jr., and M. C. Calhoun 1995. Nutrient values for cottonseed products deserve new look. Feedstuffs 67(44):10.

Hawkins, G. E., K. A. Cummins, M. Silverio, and J. J. Jilek. 1985. Physiological effects of whole cottonseed in the diet of lactating dairy cows. J. Dairy Sci. 68:2608-2614.

Hron, R. J. Sr., H. L. Kim, M. C. Calhoun, and G. S. Fisher. 1999. Determination of (+)-, (-)-, and total gossypol in cottonseed products by high performance liquid chromatography. J. Am. Oil Chem. Soc. 76:1351-1355.

Kaneko, J. J. 1989. Page 886 in Clinical Biochemistry of Domestic Animals. 4th ed. Academic Press, Inc., New York, NY.

Kim, H. L., and M. C. Calhoun. 1995. Determination of gossypol in plasma and tissues of animals. INFORM 6(4):486.(Abstr.).

Lane, A. G., and R. L. Stuart. 1990. Gossypol intake may affect vitamin status of dairy cattle. Feedstuffs $62(28): 13-14$.

Lindsey, T. O., G. E. Hawkins, and L. D. Guthrie. 1980. Physiological responses of lactating cows to gossypol from cottonseed meal rations. J. Dairy Sci. 63:562-573.

Morgan, S. E. 1989. Gossypol as a toxicant in livestock. Vet. Clin. North Am. Food Anim. Prac. 5:251-262.

National Research Council. 1989. Nutrient requirements of dairy cattle. 6th ed. Nat. Acad. Sci., Washington D.C.

Nelson, D. A. 1979. Erythrocyte disorders. Pages 964-1035 in Todd, Sanford and Davidsonhn's Clinical Diagnosis and Management by Laboratory Methods. 16th ed. J. B. Henrey, ed. W. B. Saunders Co., Philadelphia, PA.

Njeru, C. A., L. R. McDowell, R. M. Shireman, N. S. Wilkinson, L. X. Rogas, and S. N. Williams. 1995 Assessment of vitamin E nutritional status in yearling beef heifers. J. Anim. Sci. 73:1440-1448.

Reiser, R., and H. C. Fu. 1962. The mechanisms of gossypol detoxification by ruminant animals. J. Nutr. 76:215-218.

Reyes, J. J., N. Allen, A. R. Tanphaichitr, B. D. Bellve, and D. J. Benos. 1984. Molecular mechanisms of gossypol action on lipid membranes. J. Biol. Chem. 259:9607-9615.

Risco, C. A., and C. C. Chase Jr. 1997. Gossypol. Pages 87-97 in Handbook of Plant and Fungal Toxicants. CRC Press. Boca Raton, FL.

Risco, C. A., C. A. Holmberg, and A. Kutches. 1992. Effect of graded concentrations of gossypol on calf performance: Toxicological and pathological considerations. J. Dairy Sci. 75:2787-2798.

Risco C. A., P. J. Chenoweth., R. E Larsen., J. Velez, N. Shaw, T. Tran, and C. C. Chase. 1993. The effect of gossypol in cottonseed meal on performance, hematological and semen traits in post pubertal brahman bulls. Theriogenology, 40:3, 629-642.

SAS. 1996. SAS/STAT Software: 1996 SAS Inst., Inc., Cary NC.

Smalley, S. A., and E. J. Bicknell. 1982. Gossypol toxicity in dairy cattle. Compend. Contin. Educ. Prac. Vet. 4(9):5378-5381.

Smith, K. L., Hogan, J. S., and H. R. Conrad. 1988. Selenium in dairy cattle: Its role in disease resistance. Vet. Med. 83:72-78.

Stanisiewski, E. P., L. F. Krabill, and J. W. Lauderdale. 1992. Milk yield, health, and reproduction of dairy cows given somatotropin (Somavubove) beginning early postpartum. J. Dairy Sci. 75:2149.

Velasquez-Perreira, J., C. A Risco, L. R. McDowell, C. R. Staples, D. Prichard, P. J. Chenoweth, F. G. Martin., S. N. Williams, L. X. Rogas, M. C. Calhoun, and N. S. Wilkinson. 1999. Long-term effect of feeding gossypol and vitamin E to dairy calves. J. Dairy Sci. 82:1240-1251.

Wang, J. M., L. Tao, X. L. Wu, L. X. Lin, J. Wu, M. Wang, and G. Y. Zhang. 1992. Differential binding of (+)- and (-)-gossypol to plasma protein and their entry into rat testis. J. Reprod. Fert. 95:277-282

Weiss, W. P., J. S. Hogan, K. L. Smith, and K. H. Hoblet. 1990. Relationship among selenium, vitamin E, and mammary gland health in commercial dairy herds. J. Dairy Sci. 73:381-390.

Weiss, W. P., J. S. Hogan, K. L. Smith, D. A. Todhunter, and S. N. Williams. 1992. Effect of supplementing periparturient cows with vitamin $\mathrm{E}$ on distribution of $\alpha$-Tocopherol in blood. J. Dairy Sci. 75:3479-3485.

Wilcox, C. J., W. W. Thatcher, and F. G. Martin. 1990. Statistical analysis of repeated measurements in physiology experiments. Page 92 in Proc. Final Res. Coord. Mtg. FAO/IAEA/Arreglos Regionales Co-Operativas para la Promocion de la Ciencia y la Tecnologia Nucleares en America Latina III, International Atomic Energy Agency, Vienna, Austria, (Abstr.).

Willard, S. T., D. A. Neuendorff, A. W. Lewis, and R. D. Randel. 1995. Effects of free gossypol in the diet of pregnant and postpartum Brahman cows on calf development and cow performance. J. Anim. Sci. 73:496-507. 